\title{
IDENTIFIKASI KEMAMPUAN BERPIKIR KRITIS DAN EFIKASI DIRI SISWA SMA NEGERI KELAS XI IPA SEKOTA BANJARMASIN PADA MATERI LAJU REAKSI
}

\section{Identification of Critical Thinking Skills and Self Efficacy Students of Class XI IPA High School Of Banjarmasin City In Reaction Rate}

Muhammad Naparin*, Rusmansyah, Almubarak

Program Studi Pendidikan Kimia FKIP Universitas Lambung Mangkurat, J1. Brigjend. H. Hasan Basry Banjarmasin 70123 Kalimantan Selatan Indonesia *email: mnaparin1994@gmail.com

\begin{abstract}
Abstrak. Penelitian ini bertujuan mengetahui tingkat kemampuan berpikir kritis siswa SMA Negeri. Populasi dalam penelitian ini adalah seluruh siswa kelas XI SMA Negeri di kota Banjarmasin. Pengambilan sampel dilakukan dengan teknik purposive random sampling artinya dari seluruh populasi dipilih 4 SMA Negeri yang tergolong tinggi yaitu SMA Negeri 2 Banjarmasin, tergolong sedang yaitu SMA Negeri 6 Banjarmasin dan SMA Negeri 8 Banjarmasin dan tergolong rendah yaitu SMA Negeri 12 Banjarmasin. Teknik pengumpulan data menggunakan teknik tes untuk mengetahui kemampuan siswa pada materi laju reaksi kelas XI dan teknik angket. Teknik analisis data menggunakan teknik persentase. Hasil penelitian menunjukkan bahwa rata-rata kemampuan berpikir kritis siswa SMA Negeri 2 yaitu 75,5\%, lebih baik dari SMA Negeri 6 yaitu 74,5\%, SMA Negeri 8 yaitu $61,4 \%$ dan SMA Negeri 12 yaitu 57,3\%. Rata-rata sefl efficacy SMA Negeri 2 yaitu $89,6 \%$, lebih baik dari SMA Negeri 6 Banjarmasin yaitu kritis yaitu $83 \%$, SMA Negeri 8 Banjarmasin yaitu $81,4 \%$ dan SMA Negeri 12 Banjarmasin yaitu 78,7\%. Respon terhadap soal kemampuan berpikir kritis SMA Negeri 2 yaitu 44,48 dan pada SMA Negeri 6 yaitu 42,78, kateria sangat baik sedang SMA baik pada model pembelajaran problem based learning berbasis lahan basah.
\end{abstract}

Kata kunci: Kemampuan berpikir kritis, laju reaksi, self efficacy, respon

\begin{abstract}
This study at to determine the level of critical thinking skills of high school students. The population in this study were all students of class XI of state high schools in Banjarmasin. Sampling was done by using purposive random sampling technique, meaning that of the entire population, 4 high schools of SMA are selected, namely SMA Negeri 2 Banjarmasin, classified as medium, namely SMA Negeri 6 Banjarmasin and SMA Negeri 8 Banjarmasin, and relatively low, namely SMA Negeri 12 Banjarmasin. Data collection techniques using test techniques to determine the ability of students in class XI reaction rate material and questionnaire techniques. Data analysis techniques using percentage techniques. The results showed that the average critical thinking ability of SMA Negeri 2 students was $75.5 \%$, better than SMA Negeri 6 which was $74.5 \%$, SMA Negeri 8 was $61.4 \%$ and SMA Negeri 12 was $57.3 \%$. The average sefl efficacy of SMA Negeri 2 is $89.6 \%$, better than SMA Negeri 6 Banjarmasin, which is critical at 83\%, SMA Negeri 8 Banjarmasin at $81.4 \%$ and SMA Negeri 12 Banjarmasin at $78.7 \%$. The response to the critical thinking ability of SMA Negeri 2 is 44.48 and at SMA Negeri 6 is 42.78, kateria is very good while SMA Negeri 8 is 42.15 and at SMA Negeri 12 is 41.0, in good cateria.
\end{abstract}

Keywords: The ability to think critically, the rate of reaction, self efficacy, response.

Copyright $\odot$ JCAE-Jurnal Tugas Akhir Mahasiswa, e-ISSN 2613-9782

Program Studi Pendidikan Kimia FKIP Universitas Lambung Mangkurat 


\section{PENDAHULUAN}

Kemajuan suatu negara sangat membutuhkan ilmu pengetahuan yang dimiliki manusia dalam berpikir positif, sehingga mampu mengambil dengan bijaksana dalam menyelesaikan masalah kehidupan. Kemampuan berpikir dan bertindak, setiap manusiadiharapkan mampu menghadapi berbagai masalah yang sulit dalam segala permasalahan kehidupan. Ilmu pengetahuan yang (Mamu, 2013).

Mamu (2013) berpendapat bahwa aspek kemampuan berpikir kritis dan efikasi diri merupakan dua hal yang harus ada diri manusia dan perlu dibangkitkan pada perserta didik agar dapat berguna bagi diri.

Berpikir kritis yaitu proses terkumpul aktivitas mental yang ada diri manusia menganalisis permikiran, membangkitkan pengetahuan perserta didik dan mampu mengambil dengan bijaksana. Perserta didik yang memiliki kemampuan berpikir kritis mampu membuat bijaksana yang baik dalam mengambil keputusan untuk hal yang baik atau hal yang buruk. Dihubungkan dengan efikasi diri bahwa, keyakinan diri pada kemampuannya untuk membangkitkan fungsi diri mereka di lingkungannya. Bandura dalam Sulthon (2014) hubungannya dengan efikasi diri. Bandura setuju bahwa (self efficacy) berfungsi sebagai suatu determinan atau faktor membangunkan motivasi diri , afeksi dan mengambil dengan bijaksana.

Rasa memuaskan tersebut berakibat pada suatu kepribadian melalui proses kognitif, motivasional, dan afektif (Bandura, 1986). Materi laju reaksi merupakan materi yang dapat memotivasi perserta didik untuk berpikir kritis, yang mengajarkan materi teori tumbukan, faktor penentu orde reaksi dan persamaan laju reaksi. Pada aspek sains, kimia membahas berbagai memahami sifat dan proses terjadinya alam semesta (Roehrig, 2004). Aspek proses kimia adalah kemampuan diri yang diperlukan perserta didik untuk berpikir dan bijaksana dalam memecahkan masalah.

Proses pembelajaran kimia memfokuskan pada pemberian hal yang terjadi secara langsung dan kaitannya dengan fenomena alam, kegiatan eksperimen serta ilmu yang berguna untuk memahami karakter dan proses terjadinya alam semesta sekitar melalui berpikir kritis dan berusaha (Roehrig, 2004). Dengan mengkaji permasalahan-permasalahan dalam kimia melalui pembelajaran yang terencana di sekolah, dapat mebiasakan dan mengembangkan kemampuan berpikir kritis dan self efficacy (Mamu, 2013).

Definisi Corebima (2009) menyatakan bahwa membangkitkan potensi berpikir perserta. Peristiwa pembelajaran kimia yang belum memberdayakan kemampuan berpikir kritis maupun self efficacy masih terjadi dan dialami oleh para perserta didik SMA Negeri 12 di Kota Banjarmasin. Persoalan ini muncul, karena sebagian pengajar belum memahami secara utuh, kemampuan berpikir kritis dan self efficacy bagi perserta didik. Strategi pembelajaran yang diterapkan masih bersifat teacher-centered bukan student-centered. Bentuk soal-soal latihan dan soal ulangan yang digunakan dalam evaluasi umumnya bersifat hafalan seperti konsep yang digunakan $\mathrm{C} 1$ : pengetahuan, $\mathrm{C} 2$ : pemahaman dan $\mathrm{C} 3$ : penerapan (taksonomi blom), sedang critical thinking skills terdapat dari C4 sampai C6 bahwa pengajar belum mengimplementasikan konsep berpikir kritis dalam belajar kimia. Fakta ini mengindikasikan bahwa membiasakan kemampuan berpikir kritis dan self efficacy secara sadar belum terimplementasikan dalam pembelajaran kimia.

Berbanding terbalik dari kejadian dalam pembelajaran yang diuraikan di atas, dan selanjutnya untuk mencari jalan keluar memperbaikannya, maka dinilai perlu untuk mengetahui identifikasi kemampuan berpikir kritis dan self efficacy siswa yang belajar kimia SMA Negeri di Kota Banjarmasin. Identifikasi 
kemampuan berpikir kritis dan self efficacy akan dilihat berdasarkan kemampuann akademik para perserta didik, yang belum diperhatikan khusus oleh pengajar dalam menentukan strategi pembelajaran yang sesuai dengan karakter para perserta didik.

Demikian persoalan yang berhubungan dengan upaya membangkitkan potensi berpikir kritis dan self efficacy perserta didik dapat ditindak lanjuti untuk mendapatkan jalan keluar yang sesuai. Pada penelitian ini untuk mendeskripsikan identifikasi keterampilan berpikir kritis dan self efficacy siswa SMA kelas XI sekota Banjarmasin pada materi laju reaksi.

\section{METODE PENELITIAN}

Penelitian deskriptif dengan pendekatan kuantitatif itu bertujuan untuk menggambarkan dan mendeskripsikan peristiwa yang terjadi dengan apa adanya, dimana fenomena-fenomena tersebut dideskripsikan berdasarkan hasil perhitungan berupa suatu jumlah, ukuran atau frekuensi (Sugiyono, 2012).

Subjek pada penelitian ini terdiri dari 4 sekolah yang mana pengambilan sampel dilakukan dengan menggunakan teknik purposive rendon sampling, dimana dari seluruh populasi yang ada dipilih 4 SMA Negeri. Secara keseluruhan berjumlah 4 kelas, yaitu kelas XI SMA Negeri 2 Banjarmasin, kelas XI SMA Negeri 6 Banjarmasin kelas XI SMA Negeri 8 Banjarmasin dan kelas XI SMA Negeri 12 Banjarmasin.

Pengumpulan data menggunakan teknik tes dan non tes. Teknik tes berupa tes kemampuan berpikir kritis. Teknik non tes berupa teknik angket sefl efficacy, teknik wawancara dan observasi. Instrumen penelitian diujicobakan untuk mengetahui validitasnya.

\section{HASIL PENELITIAN DAN PEMBAHASAN}

Data hasil tes kemampuan berpikir kritis siswa yang dihasilkan dari berdasarkan kriteria dapat dilihat pada Tabel 1 berikut.

Tabel 1. Daftar nilai uji kemampuan berpikir kritis siswa

\begin{tabular}{cccccc}
\hline $\begin{array}{c}\text { Interval } \\
\text { Nilai } \\
(\mathbf{1 0 0 \%})\end{array}$ & Kategori & \multicolumn{4}{c}{ Frekuensi kemampuan berpikir kritis siswa } \\
\cline { 3 - 6 } & $\begin{array}{c}\text { SMAN 2 } \\
\text { Banjarmasin }\end{array}$ & $\begin{array}{c}\text { SMAN 6 } \\
\text { Banjarmasin }\end{array}$ & $\begin{array}{c}\text { SMAN 8 } \\
\text { Banjarmasin }\end{array}$ & $\begin{array}{c}\text { SMAN 12 } \\
\text { Banjarmasin }\end{array}$ \\
\hline $81-100$ & Sangat Kritis & 7 & 6 & - & - \\
$66-80$ & Kritis & 16 & 8 & 9 & 8 \\
$56-65$ & Cukup Kritis & 11 & 21 & 5 & 9 \\
$41-55$ & Kurang Kritis & - & 1 & 6 & 6 \\
$0-40$ & Tidak Kritis & - & - & - & - \\
\hline & Jumlah & 33 & 36 & 20 & 22 \\
\hline
\end{tabular}

Kemampuan berpikir kritis SMA Negeri 2 Banjarmasin memiliki kontuksi yang bervariasi. Dilihat dari grafik tingkat kemamapuan yang sangat kritis masih rendah sedang pada kategori kritis mendapatkan hasil yang tinggi namun masih banyak siswa yang berada pada kategori cukup.

Berdasarkan tabel 1 dapat dilihat bahwa nilai uji kemampuan berpikir kritis siswa di SMA Negeri 6 pada materi laju reaksi berada pada 21 siswa mendapat hasil yang tinggi yaitu cukup kritis, sedangkan pada kategori pada 6 siswa yaitu sangat kritis dan pada 8 siswa yaitu kategori kritis, namun masih siswa yang berada pada 1 siswa yaitu kurang kritis. 
Berdasarkan tabel 1 dapat dilihat bahwa nilai uji kemampuan berpikir kritis siswa di SMA Negeri 8 pada materi laju reaksi berada pada 9 siswa mendapat hasil yang tinggi yaitu kritis, sedangkan pada kategori pada 5 siswa yaitu cukup kritis namun masih siswa yang berada pada 6 siswa yaitu kurang kritis.

Berdasarkan tabel 1 dapat dilihat bahwa nilai uji kemampuan berpikir kritis siswa di SMA Negeri 12 pada materi laju reaksi berada pada 8 siswa yaitu kritis, sedangkan pada kategori cukup kritis mendapat hasil yang tinggi pada 9 siswa yaitu kritis, namun masih banyaknya siswa yang berada pada 6 yaitu kurang kritis.

Kemampuan berpikir kritis SMA Negeri 2 Banjarmasin memiliki kontuksi yang bervariasi. Dilihat dari grafik tingkat kemamapuan yang sangat kritis masih rendah sedang pada kategori kritis mendapatkan hasil yang tinggi namun masih banyak siswa yang berada pada kategori cukup.

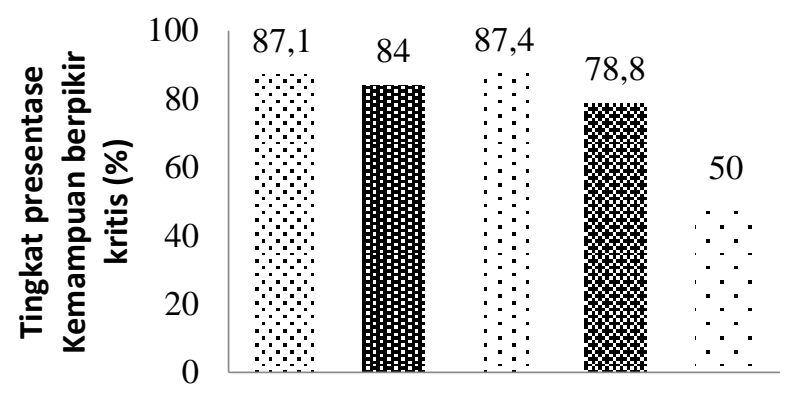

$\therefore$ Soal 1 : Soal 2 : Soal $3 \bowtie$ Soal $4 \cdot$ Soal 5

\section{Gambar 1. Hasil uji kemampuan berpikir kritis SMA Negeri 2 Banjarmasin}

Pada gambar 1 didapatkan hasil uji kemampuan berpikir kritis SMA Negeri 2 Banjarmasin tiap soal. Hal ini memperlihatkan bahwa siswa pada sudah Negeri 2 cukup kritis meskipun mampu dalam memcahkan masalah yang telah dipecahkan.

Soal yang mengukur kemampuan berpikir kritis yang sukar dan tentunya pada soal ini berkaitan dengan soal lain. Apabila soal lain belum bisa terpecahkan, maka siswa belum bisa memecah masalah pada soal ini. Walaupun bisa menjawab, tapi jawabannya dengan belum tidak tepat atau tidak sesuai karena siswa harus bisa dahulu menjawab soal lainnya. Namun, pada gambar 1 siswa belum cukup mampu dalam memecahkan masalah dibuktikan dengan hasil uji kemampuan berpikir kritis memiliki nilai rata-rata yang terendah yaitu 50 untuk kritis SMA Negeri 2 Banjarmasin. Berikut perbandingan jawaban siswa untuk soal nomor 5 pada SMA Negeri 2 Banjarmasin dari satu soal, yakni :

Dalam proses metabolisme terdapat faktor yang berpengaruh pada kerja. Didit sering melakukan olahraga berat. Apabila kita melakukan olahraga maka terjadi peningkatan suhu dapat meningkatkan kecepatan reaksi sampai batas suhu tertentu. Energi adenosine triphosphate menghasilkan sumber energi, selain itu ketika kita berolahraga suhu enzim terus menerus naik, maka kemampuan kerja enzim menurun, bahkan berhenti. Contohnya penurunan suhu, maka enzim tidak bisa bekerja karena menjadi tidak aktif pada suhu rendah $\left(0^{\circ} \mathrm{C}\right.$ atau di bawahnya), tetapi tidak rusak. Apa reaksi yang terjadi tersebut :

a. Coba kalian temukan masalah pada pada ilustrasi diatas. Buatlah pertanyaan dari masalah tersebut? (Indikator berpikir kritis: Memfokuskan pertanyaan)

b. Informasi apa saja yang dapat dijabarkan dari permasalahan tersebut? (Indikator berpikir kritis: mendeduksi) 
c. Berdasarkan ilustrasi di atas selidiki lah permasalah tersebut? (Indikator berpikir kritis: memutuskan suatu tindakan)

d. Kesimpulan apa yang dapat kamu ambil dari permasalahan Marsya tersebut? ( Indikator berpikir kritis: menginduksi)

Jawaban dinilai tepat apabila memberikan memecahkan masalah dengan tepat dari permasalahan. Karena kalau dilihat : Semakin besar konsentrasi asam klorida, semakin cepat waktu sedangkan semakin kecil luas permukaan sentuh batu pualam semakin lama waktu. Ok, Jadi kamu bandingkan waktu konsentrasi dengan luas permukaan.

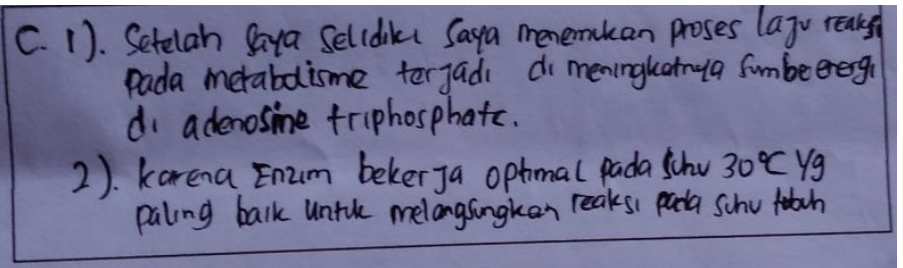

Gambar 2. Jawaban perserta didik yang tepat pada soal 5C

Gambar 2 memperlihatkan bahwa perserta didik sudah mampu memecahkan masalah, namun masih kurang tepat. Karena saya belum memahami maksud soal tersebut. Penjelasan siswa tersebut memberikan jawaban secara umum, belum dijelaskan secara detail.

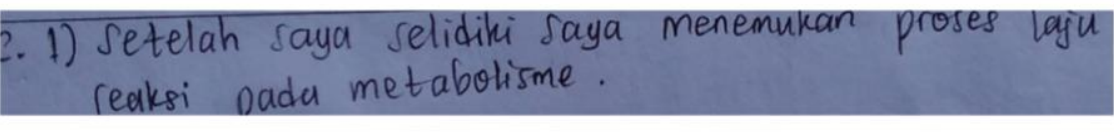

Gambar 3. Jawaban peserta didik yang belum tepat pada soal 5C

Gambar 3 memperlihatkan bahwa siswa sudah mampu memecahkan masalah dan juga masih kurang tepat. Penjelasan yang diberikan sudah cukup rinci akan tetapi belum lengkap. Hal ini yang menyebabkan siswa berada pada 33,3\% kategori cukup kritis.

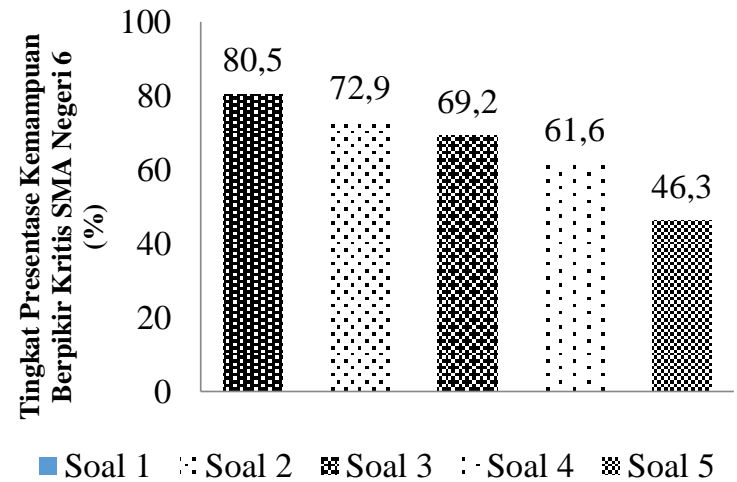

\section{Gambar 4. Hasil uji kemampuan berpikir kritis SMA Negeri 6 Banjarmasin}

Pada gambar 4 didapatkan hasil uji kemampuan berpikir kritis SMA Negeri 6 Banjarmasin tiap soal. Soal untuk indikator ini terdiri dari 4 soal, yang mana 1 soal termasuk kategori sedang dan 5 soal termasuk kategori sukar. Bentuk soal dari 
indikator ini menentukan terjadinya metabolisme dalam tubuh manusia.

Berdasarkan pembahasan di atas, bahwa soal siswa masih sulit menjawab dengan baik sedangkan pada soal 4 siswa mampu menjawab dengan baik. Selain itu, hal ini juga tergambar dari hasil uji kemampuan berpikir kritis yang diberikan pada siswa. Berikut ini juga ditampilkan contoh hasil uji kemampuan berpikir kritis siswa pada siswa. Berdasarkan gambar 5 di bawah, terlihat bahwa perserta didik telah mampu menyelesaikan lembar soal yang diberikan oleh pengajar.

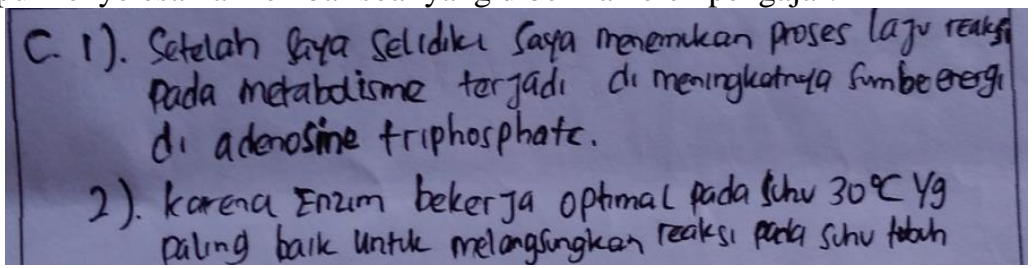

Gambar 5. Jawaban siswa yang tepat pada soal 5C

Hal ini berarti siswa telah mampu memahami materi laju reaksi dan mampu menyelesaikan soal tersebut, seperti yang ditanyakan dari lembar soal yang disajikan. Dengan demikian, perserta didik tersebut mendapatkan jawaban yang sesuai dengan soal yang diberikan guru, sehingga dilihat dari jawaban tersebut dapat dikatakan bahwa mampu menghasilkan kemampuan berpikir kritis.

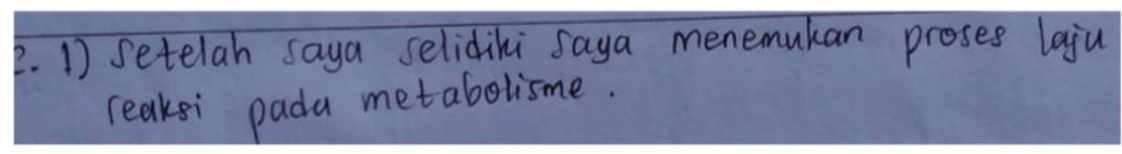

Gambar 6. Jawaban siswa yang nilai terendah pada soal 5c

Berdasarkan gambar 6, terlihat bahwa peserta didik belum mampu dalam menyelesaikan lembar soal yang diberikan oleh pengajar. Hal ini berarti perserta didik kurang sungguh-sungguh memahami materi laju reaksi dan kurang mampu menyelesaikan soal tersebut, siswa tersebut kurang mampu membuktikan jawaban yang sesuai dengan soal yang diberikan guru, sehingga dilihat dari jawaban tersebut hasil yang diperolehnya pun menjadi rendah. Berikut ini juga ditampilkan contoh hasil uji kemampuan berpikir kritis yang memperoleh nilai tertinggi dan nilai terendah.

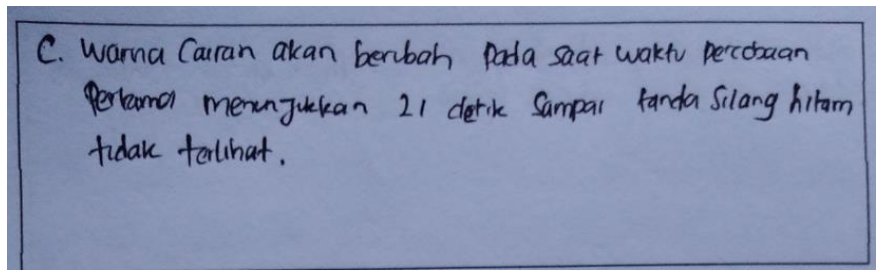

Gambar 7. Contoh jawaban siswa yang nilai tertinggi pada soal 4

Berdasarkan gambar 5, terlihat bahwa pada soal 4 telah mampu menyelesaikan lembar soal yang diberikan oleh pengajar, perserta didik tersebut mendapatkan jawaban yang sesuai dengan soal yang diberikan guru. 


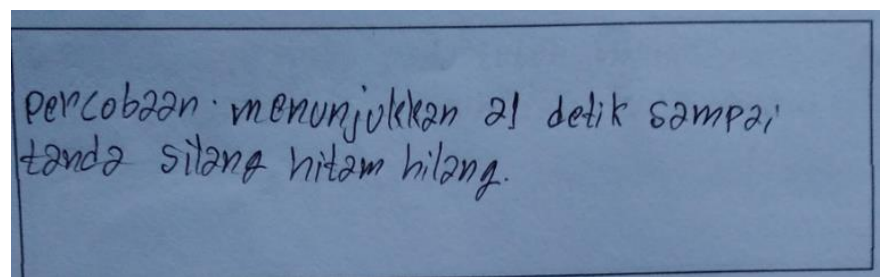

Gambar 8. Contoh jawaban siswa yang nilai terendah pada soal 4

Berdasarkan gambar 8, terlihat bahwa siswa kurang mampu dalam menyelesaikan masalah dan memahami materi lajua reaksi. Sebagian siswa masih belum terbiasa dengan tipe soal yang diberikan. Dengan demikian, siswa tersebut kurang mampu membuktikan jawaban yang sesuai dengan soal yang diberikan oleh pengajar, sehingga dilihat dari jawaban tersebut hasil belajar yang diperolehnya pun menjadi rendah. Siswa yang berada pada kategori kurang cukup yaitu 2,8.

Berdasarkan gambar 9 dapat dilihat bahwa nilai uji kemampuan berpikir kritis perserta didik di SMA Negeri 8 pada materi laju reaksi berada pada 45 mendapat hasil yang tinggi yaitu kritis, sedangkan pada kategori pada 25 yaitu cukup kritis namun masih siswa yang berada pada 30 yaitu kurang kritis.

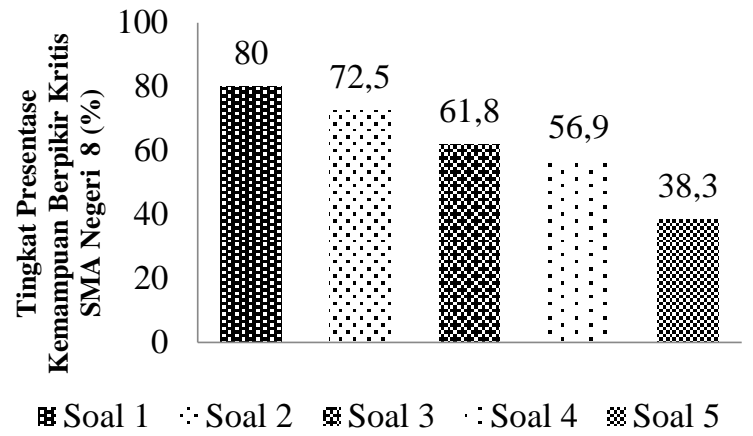

\section{Gambar 9. Hasil uji kemampuan berpikir kritis SMA Negeri 8 Banjarmasin}

Pada gambar 9 didapatkan hasil uji kemampuan berpikir kritis SMA Negeri 8 Banjarmasin tiap soal. Bentuk soal 1 ini berupa soal cerita yang mana siswa disuruh menemukan permasalahan dari soal. Gambar 11 menunjukkan bahwa pemahaman siswa pada soal 1 lebih tinggi dari soal 5 yaitu $38,3 \%$ dan untuk soal satu $80 \%$. Namun, selisih nilai rata-rata kedua soal tersebut jauh berbeda yaitu $41,7 \%$, hal ini menunjukkan soal 1 lebih menguasai dari soal 5.

Pemahaman siswa pada soal 1 lebih tinggi karena pada soal ini siswa mengemukakan pendapat dengan pemikiran siswa sehingga optimal membantu siswa dalam menemukan konsep dan memecahkan permasalahan. Menurut Yunita menyatakan bahwa kemampuan berpikir kritis siswa beum mencapai kemamapuan berpikir sangat kritis. Pada soal 5 kurang aktif berperan dalam menemukan konsep dan memecahkan masalah sehingga tingkat pemahamannya lebih rendah (Asranudin, 2017).

Berdasarkan gambar 10 di bawah ini, dapat dilihat bahwa nilai uji kemampuan berpikir kritis siswa di SMA Negeri 12 pada materi laju reaksi berada pada 36,4 yaitu kritis, sedangkan pada kategori cukup kritis mendapat hasil yang tinggi pada 40,9 yaitu kritis, namun masih banyaknya siswa yang berada pada 27,3 yaitu kurang kritis. 


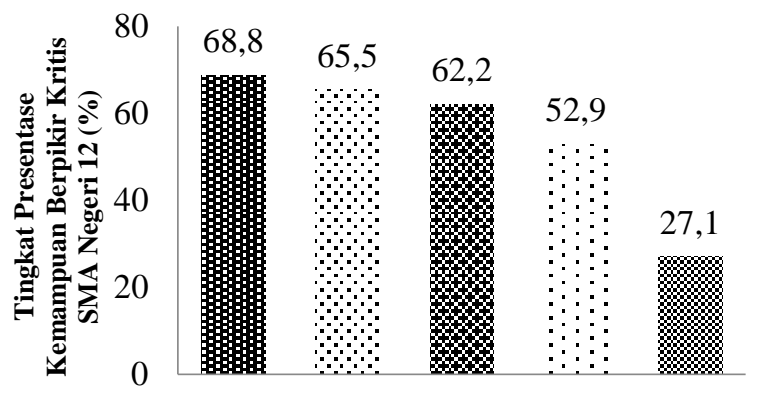

B Soal $1 \quad \because$ Soal $2 \approx$ Soal $3 \quad ; \cdot$ Soal $4 \approx$ Soal 5

\section{Gambar 10. Hasil uji kemampuan berpikir kritis SMA Negeri 12 Banjarmasin}

Pada grafik 10 didapatkan hasil uji kemampuan berpikir kritis SMA Negeri 12 Banjarmasin tiap soal. Soal untuk indikator ini terdiri dari 5 soal termasuk kategori sukar. Bentuk soal dari indikator ini menentukan terjadinya metabolisme dalam tubuh manusia.

Berdasarkan pembahasan di atas, bahwa soal siswa masih sulit menjawab dengan baik karena siswa pada soal 5 belum tidak percaya diri dalam mengerjakan tes terlihat sebelum soal tes dibagikan ada siswa sudah ingin menyerah tanpa mengetahui tes terlebih dahulu, dan tidak percaya diri dalam jawabannya sendiri sehingga menyebabkan siswa menyontek atau berdiskusi. Menyebabkan siswa berada pada $27,3 \%$ kategori kurang kritis.

\section{Angket Efikasi Diri}

Gambar 11 menunjukkan penilaian rata-rata angket self efficacy dimana apsek 1 lebih tinggi yaitu sebesar 91,1\% dibandingkan apsek 4 yaitu sebesar 87,8. Berdasarkan data tersebut bahwa pada apsek 1 yang termasuk kategori yang sangat baik sedangkan apsek 4 pada yang termasuk kategori yang sangat baik tapi nilainya lebih rendah.

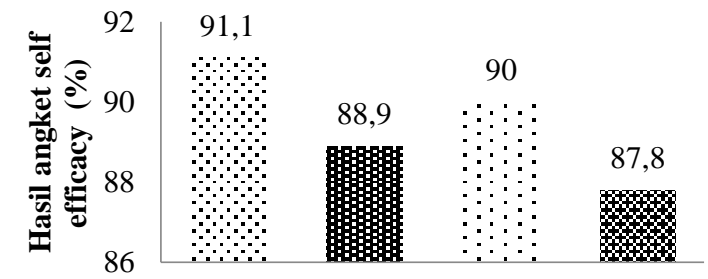

$\therefore$ Aspek 1 Baspek $2 \cdot$ Aspek $3 \otimes$ Aspek 4

\section{Gambar 11. Hasil angket efikasi diri SMA Negeri 2 Banjarmasin}

Hasil angket efikasi diri dapat dilihat dari grafik hasil persentase tiap aspek untuk SMA Negeri 2 Banjarmasin disajikan pada gambar 11 di atas. Bahwa hasil terendah terdapat pada aspek 4 yaitu 87,8. Aspek 4 ialah merupakan aspek keyakinan terhadap kemampuan menghadapi masalah yang muncul. Pada aspek ini terdiri dari 5 pernyataan yang dijawab siswa saat mengisi angket self efficacy. Aspek 4 pada gambar 10 bahwa kepercayaan diri SMA Negeri 2 ini termasuk kategori yang sangat baik untuk SMA Negeri 2 Banjarmasin. 
Berdasarkan pembahasan-pembahasan pada keempat aspek tersebut, secara keseluruhan bahwa SMA Negeri 2 Banjarmasin yang menerapkan tes kemampuan berpikir kritis lebih baik dan meningkatnya self efficacy yang ada pada diri masingmasing siswa SMAN 2 Banjarmasin tapi siswa yakin mengatasi masalah yang muncul yang dihadapinya.

Gambar 12 di bawah ini menunjukkan penilaian rata-rata angket efikasi diri dimana apsek 3 lebih tinggi yaitu sebesar 90\% dibandingkan apsek 2 yaitu sebesar $78, \%$. Berdasarkan data tersebut bahwa pada apsek 3 yang termasuk kategori yang sangat baik sedangkan apsek 2 pada yang termasuk kategori yang baik.

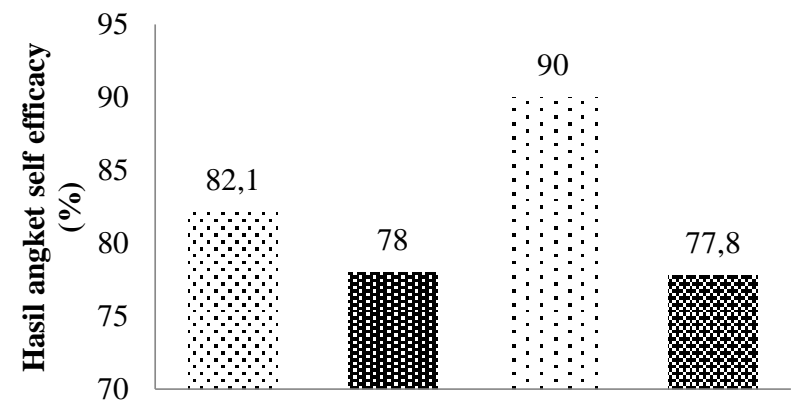

$\because$ Aspek 1 Aspek 2 : Aspek 3 Aspek 4

\section{Gambar 12. Hasil angket efikasi diri SMA Negeri 6 Banjarmasin}

Aspek kedua ini merupakan hasil angket efikasi diri dapat dilihat dari grafik hasil persentase tiap aspek untuk SMA Negeri 6 Banjarmasin disajikan pada gambar 12 di atas. Bahwa hasil terendah terdapat pada aspek 2 yaitu 78. Pada aspek ini terdiri dari 4 pernyataan yang diisi dengan skala Likert saat mengisi angket self efficacy oleh siswa.

Gambar 12 menunjukkan pada aspek 4 kepercayaan diri lebih tinggi dibanding aspek 2. Kepercayaan diri pada aspek 4 ini termasuk kategori yang sangat baik untuk dan kategori baik untuk aspek 2 . Kemampuan tersebut tersimpan di setiap diri perserta didik, belum melaksanakan motivasi. Sedangakan pada aspek 4 keyakinan mencapai target yang telah ditentukan berada pada kategori sangat baik (Wati, Rusmansyah, dan Sholahuddin, 2014).

Gambar 13 menunjukkan penilaian rata-rata angket self efficacy dimana apsek 3 lebih tinggi yaitu sebesar 89,4\% dibandingkan apsek 2 yaitu sebesar 78 . Berdasarkan data tersebut bahwa pada apsek 3 yang termasuk kategori yang sangat baik sedangkan aspek 2 pada yang termasuk kategori yang baik.

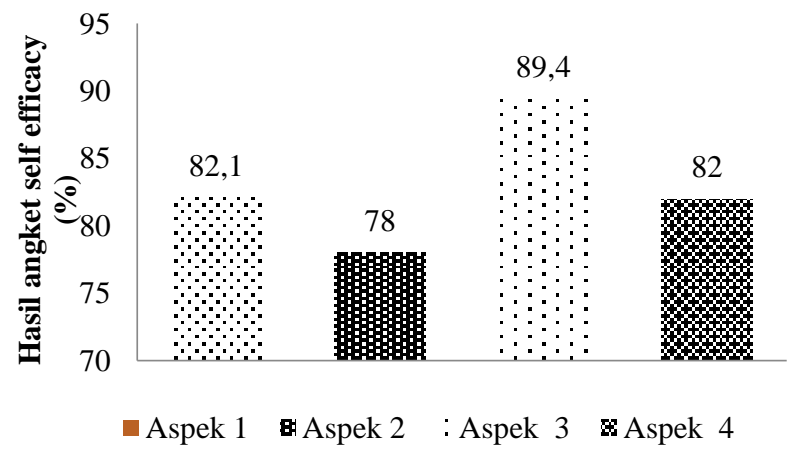

Gambar 13. Hasil angket efikasi diri SMA Negeri 8 Banjarmasin 
Pada aspek kedua hasil angket efikasi diri dapat dilihat dari grafik hasil persentase tiap aspek untuk SMA Negeri 8 Banjarmasin disajikan pada gambar 13 di atas. Bahwa hasil angket self efficacy pada aspek 2 yaitu 78. Pada kepercayaan diri pada aspek 2 ini termasuk kategori yang baik tapi kurang dorogan motivasi guru pada siswa yang rendah keyakinana siswa.

Gambar 14 menunjukkan penilaian rata-rata angket self efficacy dimana aspek 2. Berdasarkan data tersebut bahwa pada aspek 2 yang termasuk kategori yang baik tapi nilainya terendah.

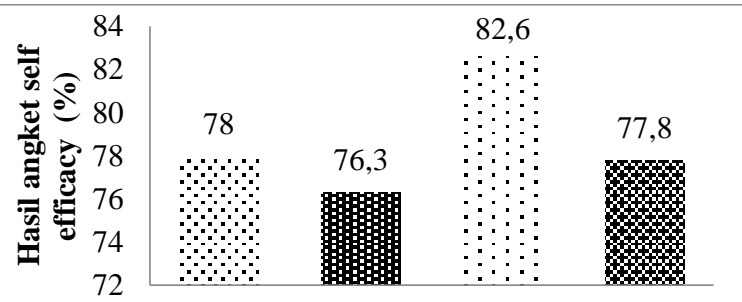

$\because$ Aspek 1 aspek 2 Aspek 3 Aspek 4

\section{Gambar 14. Hasil angket efikasi diri SMA Negeri 12 Banjarmasin}

Aspek kedua ini hasil angket efikasi diri dapat dilihat dari grafik hasil persentase tiap aspek untuk SMA Negeri 12 Banjarmasin disajikan pada gambar 14 di atas. Bahwa hasil angket self efficacy pada aspek 2 yaitu 76,3\%.

Pada dasarnya perserta didik telah memiliki efikasi diri yang kepercayaan baik tersebut hanya membutuhkan peningkatan yang kecil. Sebagian besar siswa memiliki self efficacy awal yang kategori yang baik. Tidak ada siswa yang memiliki self efficacy yang buruk. Kemampuan tersebut tersimpan di setiap diri siswa dan belum ada yang membimbing untuk mengeksplorasi sehingga bermanfaat dalam persaingan dunia global berdasarkan penelitian Hanifah dan Agustini (2012).

\section{Tabel 2. Respon siswa SMA Negeri se-kota Banjarmasin}

\begin{tabular}{cccc}
\hline No & \multicolumn{1}{c}{ Kelas } & Nilai rata-rata respon siswa & Kriteria \\
\hline 1 & SMAN 2 Banjarmasin & 44,48 & Baik \\
2 & SMAN 6 Banjarmasin & 42,78 & Baik \\
3 & SMAN 8 Banjarmasin & 42,15 & Baik \\
4 & SMAN 12 Banjarmasin & 41,05 & Baik \\
\hline
\end{tabular}

Tabel 2 menunjukkan bahwa Hasil angket menunjukan adanya respon yang positif terhadap soal kemampuan berpikir kritis. Data terdari 44,48 siswa merespon sangat setuju pada SMA Negeri 2 Banjarmasin, sedangkan SMA Negeri 6 Banjarmasin dengan nilai 42,78 SMA Negeri 8 dengan nilai 42,15 dan SMA Negeri 12 Banjarmasin dengan nilai 41,05.

\section{SIMPULAN}

Simpulan yang dapat ditarik adalah (1) Terdapat perbedaan kemampuan berpikir kritis yang signifikan antara siswa SMAN 2 dangan siswa SMAN 6, SMAN 8, SMAN 12 yang pada materi laju reaksi, (2) Efikasi diri yang dimiliki oleh perserta didik SMAN 2 lebih baik dibandingkan siswa SMAN 6, SMAN 8, SMAN 12 karena mendapatkan hasil tertinggi yaitu 75,5, (3) Perserta didik memberikan respon yang lebih positif terhadap soal kemampuan berpikir kritis dengan menjawab soal kemampuan berpikir kritis. 


\section{DAFTAR RUJUKAN}

Rusmansyah, R., \& Asranudin, A. (2017). Application of GI-TPS Model to Skills Critical Thinking and Self Efficacy. Journal of Educational Science and Technology (EST), 3(3), 198-203.

Bandura. (1986). Social Foundations Of Thought and Action. A Social.

Corebima. A. D. (2009). Pelatihan PBMP (Peberdayaan Berpikir Melalui Pertanyaan) Pada Pembelajaran Bagi Para Guru dan Mahasiswa Sains Biolog dalm Rangka RUKK VA. 25 Juni.

Depdiknas. (2006). Model Silabus dan Rencana Pelaksanaan Pembelajaran Mata Pelajaran Ilmu Pengetahuan Alam. Jakarta: Depertemen Pendidikan Nasional.

Dilekli. Y. (2017). The Relationships Between Critical Thinking Skills And Learning Styles Of Gifted Students. European Jornal Of Education Studies, 2 (2).

Endriani, R., Sundaryono, A., \& Elvia, R. (2018). Pengembangan Media Pembelajaran Kimia Menggunakan Video untuk Mengukur Kemampuan Berfikir Kritis Siswa. PENDIPA Journal of Science Education, 2(2), 142146.

Hanifah, N. H. (2012). Peningkatan Self Efficacy Dan Berpikir Kritis Melalui Penerapan Model Pembelajaran Inkuiri Materi Pokok Asam Basa Kelas XI SMAN 9 Surabaya (Increase In Self Efficacy And Critical Thinking Through Implementation Model Study Of Inkuiry On Subject Matter O. Unesa Journal of Chemical Education, 1(2).

Hayudiyani, M., Arif, M., \& Risnasari, M. (2017). Identifikasi Kemampuan Berpikir Kritis Siswa Kelas X TKJ Ditinjau Dari Kemampuan Awal dan Jenis Kelamin Siswa di SMKN 1 Kamal. Jurnal Ilmiah Edutic, 4(1), 21-27.

Inggriyani. F dan Fazriyah. N. (2015). Analisis Kemampuan Berpikir Kritis Siswa Dalam Pembelajaran Menulis Narasi di Sekolah Dasar. Jurnal Pendidikan Dasar, 8 (1).

Jatisunda. M. G. (2017). Hubungan Self Efficacy Siswa SMP dengan Kemampuan Pemecahan Masalah Matematis. Jurnal Theorems (The Original Research Of Mathematics), 1 (2).

Lavadores. A. K. C, Escobedo. P. S and Sosa. J. P. (2017). Academia Self Efficacy Of High Achieving Students In Mexico. Journal Of Curriculum And Teaching, 6 (2).

Listiani, W. O. (2019). Peningkatan Kemampuan Berpikir Kritis Matematik Dan Self-Efficacy Siswa Sekolah Menengah Atas Dengan Model Pembelajaran Berbasis Masalah Kontekstual. Jurnal Pendidikan Matematika, 8(1), 67-77.

Mamu, H. D. (2014). Profil keterampilan berpikir kritis dan metakognisi siswa dalam pembelajaran IPA Biologi di SMP. Kreatif, 17(3).

Nugraha, A. J., Suyitno, H., \& Susilaningsih, E. (2017). Analisis kemampuan Berpikir Kritis Ditinjau dari Keterampilan Proses Sains dan Motivasi Belajar melalui Model PBL. Journal of Primary Education, 6(1), 35-43.

Rahdar. A, Pourghaz. A and Marziyeh. A. (2018). The Impact Teaching Philosophy For Children on Critical Openness and Reflective Skepticism in Developing Critical Thinking and Self Efficacy. International Journal Of Instruction, 11 (3).

Salbiah, S. (2017). Profil Keterampilan Berpikir Kritis Siswa Menggunakan Pembelajaran Discovery Inquiry pada Konsep Koloid. JTK (Jurnal Tadris Kimiya), 2(1), 109-115. 
Siregar, Y. A., \& Sukatno, S. (2017). Hubungan Self-Efficacy dan Sikap Positif terhadap Prestasi Akademik Siswa SMK Negeri 1 Sipirok. MES: Journal of Mathematics Education and Science, 3(1), 22-29.

Sugiyono. (2012). Metode Penelitian Pendidikan Pendekatan Kuantitatif, Kualitatif dan $R \& D$. Bandung: Alfabeta.

Suhendi, H. Y., Utari, S., \& Hasanah, L. (2018). Profil Kemampuan Berpikir Kritis dan Peningkatan Prestasi Belajar Siswa SMA melalui Penerapan Strategi Problem Solving dengan Reading Infusion. Gravity: Scientific Journal of Research and Learning Physics, 4(1).

Sulthon. (2014). Membangun Efikasi Diri Untuk Meningkatkan Performansi Siswa di Sekolah. Journal Elementary, 2 (2).

Toppin. N and Chitsonga. S. (2016). Critical Thinking Skills and Academic Maturity : Emerging Results From A Five-Year Quality Enhancement Plan (QEP) Study. Journal Of Inquiry \& Action In Education, 7 (2).

Wati, R., Rusmansyah, R., \& Sholahuddin, A. (2016). Meningkatkan Kemampuan Berpikir Kritis dan Hasil Belajar Siswa Kelas XI IPA 2 SMA PGRI 4 Banjarmasin Pada Konsep Sistem Koloid Melalui Model Problem Based Learning. Quantum: Jurnal Inovasi Pendidikan Sains, 5(2).

Yunita, S., Rohiat, S., \& Amir, H. (2018). Analisis Kemampuan Berpikir Kritis Mata Pelajaran Kimia pada Siswa Kelas XI IPA SMAN 1 Kepahiang. Alotrop, 2(1).

Zulfatin, V. L. (2014). Profil keterampilan proses sains siswa SMA dalam kegiatan praktikum materi elastisitas yang dinilai menggunakan penilaian kinerja (Doctoral dissertation, Universitas Pendidikan Indonesia). 